\title{
Effects of sandfish (Holothuria scabra) removal on shallow- water sediments in Fiji
}

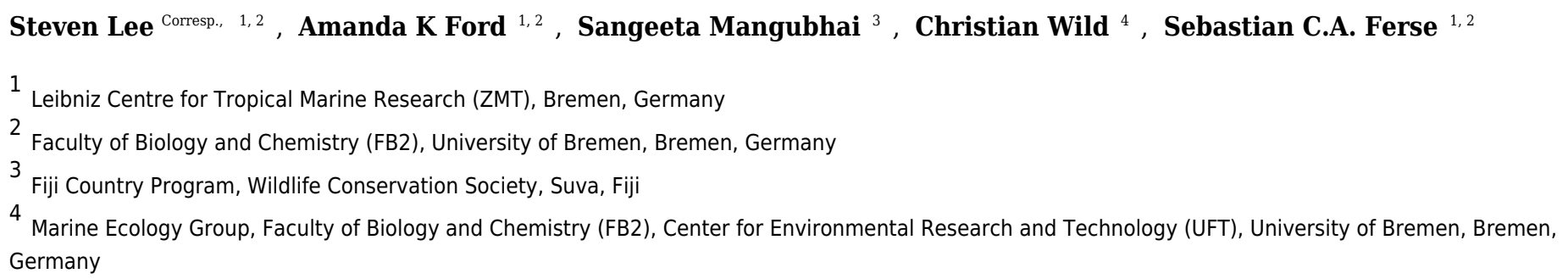

Sea cucumbers play an important role in the recycling and remineralization of organic matter (OM) in reef sands through feeding, excretion, and bioturbation processes. Growing demand from Asian markets has driven the overexploitation of these animals globally. The implications of sea cucumber fisheries for shallow coastal ecosystems and their management remain poorly understood. To address this knowledge gap, the current study manipulated densities of Holothuria scabra within enclosures on a reef flat in Fiji, between August 2015 and February 2016, to study the effects of sea cucumber removal on sedimentary function as a biocatalytic filter system. Three treatments were investigated:

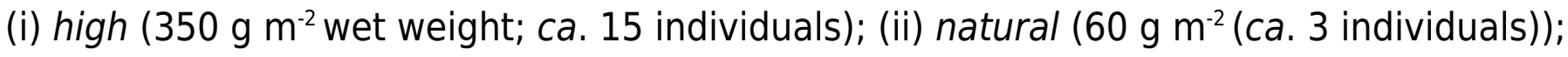
and (iii) exclusion $\left(0 \mathrm{~g} \mathrm{~m}^{-2}\right)$. Quantity of sediment reworked through ingestion by $\mathrm{H}$. scabra, grain size distribution, $\mathrm{O}_{2}$ penetration depth, and sedimentary oxygen consumption (SOC) were quantified within each treatment. Findings revealed that the natural population at the study site can rework ca. $10590 \mathrm{~kg}$ dry sediment $1000 \mathrm{~m}^{-2}$ year ${ }^{-1}$; more than twice the turnover recorded for $\mathrm{H}$. atra and Stichopus chloronotus. There was a shift towards finer fraction grains in the high treatment. In the exclusion treatment, the $\mathrm{O}_{2}$ penetration depth decreased by $63 \%$ following a $6 \% \mathrm{C}$ increase in water temperature over the course of two months, while in the high treatment no such change was observed. SOC rates increased ca. two-fold in the exclusion treatment within the first month, and were consistently higher than in the high treatment. These results suggest that the removal of sea cucumbers can reduce the capacity of sediments to buffer OM pulses, impeding the function and productivity of shallow coastal ecosystems. 
3 Steven Lee*

4 Leibniz Centre for Tropical Marine Research (ZMT), Bremen, Germany

5 Faculty of Biology and Chemistry (FB2), University of Bremen, Bremen, Germany

6 Present address: P.O. Box 4332, Nadi, Fiji Islands

7

8 Amanda K. Ford

9 Leibniz Centre for Tropical Marine Research (ZMT), Bremen, Germany

10 Faculty of Biology and Chemistry (FB2), University of Bremen, Bremen, Germany

12 Sangeeta Mangubhai

13 Wildlife Conservation Society, Fiji Country Program, 11 Ma'afu Street, Suva, Fiji

15 Christian Wild

16 University of Bremen, Marine Ecology Group, Faculty of Biology and Chemistry (FB2), Center

17 for Environmental Research and Technology (UFT), Leobener Str. 6, 28359, Bremen, Germany

19 Sebastian C.A. Ferse

20 Leibniz Centre for Tropical Marine Research (ZMT), Bremen, Germany;

21 Faculty of Biology and Chemistry (FB2), University of Bremen, Bremen, Germany

$23 *$ Corresponding author: Steven Lee 
24 Tel: +6799212735

25 Email: steven.d.a.lee@gmail.com

\section{ABSTRACT}

28 Sea cucumbers play an important role in the recycling and remineralization of organic matter $29(\mathrm{OM})$ in reef sands through feeding, excretion, and bioturbation processes. Growing demand 30 from Asian markets has driven the overexploitation of these animals globally. The implications 31 of sea cucumber fisheries for shallow coastal ecosystems and their management remain poorly 32 understood. To address this knowledge gap, the current study manipulated densities of Holothuria scabra within enclosures on a reef flat in Fiji, between August 2015 and February 342016 , to study the effects of sea cucumber removal on sedimentary function as a biocatalytic 35 filter system. Three treatments were investigated: (i) high $\left(350 \mathrm{~g} \mathrm{~m}^{-2}\right.$ wet weight; ca. 15 36 individuals); (ii) natural (60 $\mathrm{g} \mathrm{m}^{-2}$ (ca. 3 individuals)); and (iii) exclusion (0 $\left.\mathrm{g} \mathrm{m}^{-2}\right)$. Quantity of

37 sediment reworked through ingestion by $H$. scabra, grain size distribution, $\mathrm{O}_{2}$ penetration depth, 38 and sedimentary oxygen consumption (SOC) were quantified within each treatment. Findings

39 revealed that the natural population at the study site can rework $c a .10590 \mathrm{~kg}$ dry sediment 1000 $40 \mathrm{~m}^{-2}$ year-1 $^{-1}$ more than twice the turnover recorded for H. atra and Stichopus chloronotus. There 41 was a shift towards finer fraction grains in the high treatment. In the exclusion treatment, the $\mathrm{O}_{2}$ 42 penetration depth decreased by $63 \%$ following a $6^{\circ} \mathrm{C}$ increase in water temperature over the 43 course of two months, while in the high treatment no such change was observed. SOC rates 44 increased $c a$. two-fold in the exclusion treatment within the first month, and were consistently 45 higher than in the high treatment. These results suggest that the removal of sea cucumbers can 46 reduce the capacity of sediments to buffer OM pulses, impeding the function and productivity of 
47 shallow coastal ecosystems.

\section{INTRODUCTION}

54 Marine coastal ecosystems are among the most productive and diverse on earth (Poore \&

55 Wilson, 1993). Coastal communities are reliant on the various ecosystem functions and services

56 these areas provide for their livelihoods (Conservation International, 2008). Recent studies have

57 identified significant ecological impacts when benthic marine organisms were removed from

58 these ecosystems (Lohrer, Thrush \& Gibbs, 2004; Solan et al., 2004). A loss in bioturbation (the

59 biogenic mixing of sediment) has been demonstrated following the reduction in abundance and

60 diversity of marine benthic fauna (Solan et al., 2004). This loss is of particular concern as

61 bioturbation has a substantial influence on the rate of organic matter (OM) decomposition and

62 nutrient recycling (Meysman et al., 2006). Efficient processing of OM and nutrients in marine

63 coastal ecosystems is crucial to the health and productivity of these ecosystems, and as such is

64 vital to the coastal communities dependent on them.

65

66 The majority of $\mathrm{OM}$ in marine coastal ecosystems is trapped in permeable reef sands and

67 degraded by the infaunal community, particularly high densities of sand-associated microbes

68 (Wild et al., 2004a). Due to the high surface area of permeable carbonate reef sands and 69 advective flow into and within the sediment, these sandy sediments promote efficient 
70 degradation of OM (Wild et al., 2004a; Wild, Laforsch \& Huettel 2006). Such sandy sediments

71 have consequently been referred to as a biocatalytic filter system, promoting critical recycling

72 processes (Wild, Tollrian \& Huettel 2004b; Huettel et al., 2006). Benthic-pelagic coupling

73 implies that changes in the OM concentration of overlying water are integrated and reflected in

74 sediments, and furthermore that changes in sediment OM composition affect the overlying water

75 quality (Wild, Tollrian \& Huettel, 2004b). Thus, the efficient functioning of this biocatalytic

76 filter system provides coastal ecosystems - which are increasingly stressed by OM enrichment

77 from anthropogenic inputs (Halpern et al., 2008; Rabalais et al., 2009) - with buffering capacity.

78 Without the capacity of the system to buffer increasing OM loads, the health of coastal

79 ecosystems could be compromised, resulting for example in shifts from hard coral- to algal-

80 dominated reefs (Fabricius, 2005; D’Angelo and Wiedenmann, 2014).

82 Coral reefs are a critically important component of coastal ecosystems for the ecosystem services

83 and goods they provide, such as fisheries, coastal protection, and nutrient cycling (Moberg \&

84 Folke, 1999). Inshore reefs and their associated ecosystems receive a considerable amount of

85 OM from rivers and marine sources. The quantity of OM that reaches inshore reefs increases

86 following heavy rainfall and flooding events (Briand et al., 2015) - delivering a 'pulse' of OM

87 that places further stress on the ecosystem. The efficiency of the system to absorb this stress and

88 act as a biocatalytic filter is dependent on a number of factors including temperature, OM supply,

89 light, water currents, and bioturbation (Kristensen, 2000). Bioturbation is particularly important

90 for the efficiency of this filter system (Kristensen, 2000) as it increases the surface area of the

91 sediment, breaks down geochemical gradients, and maximizes advective flow into the sediment 
92 (Thibodeaux \& Boyle, 1987; Kristensen, 2000; Lohrer, Thrush \& Gibbs, 2004; Meysman,

93 Middleburg \& Hiep, 2006).

95 Deposit feeding sea cucumbers mainly of the order Holothuriida potentially play a significant role in enhancing $\mathrm{OM}$ mineralization through bioturbation as well as through feeding and excretion (Uthicke, 1999; 2001a, 2001b; Purcell, 2004; Wolkenhauer et al., 2010; MacTavish et al., 2012). Whilst sea cucumbers were once a ubiquitous component of many coastal marine benthic communities, growing demand from Asian markets for their dried form - known as bêche-de-mer - has driven their overexploitation, leading to population collapse and local extinctions throughout the Indo-Pacific (e.g. Toral-Granda, Lovatelli \& Vasconcellos, 2008; Friedman et al., 2009, 2011; Purcell et al., 2013). Sandfish, Holothuria scabra (Jaeger, 1833), is one of the highest valued species in the bêche-de-mer trade (Purcell, 2014). Individuals of this species are easily accessible to fishers as they generally inhabit low energy environments behind fringing reefs or within protected bays and shores (Hamel et al., 2001), rendering the species particularly vulnerable to overexploitation. H. scabra exhibits a natural diurnal burying cycle and

107 ingests a considerable amount of sediment during feeding, thus playing a key role in bioturbation

108 (Mercier, Battaglene \& Hamel, 1999; Purcell, 2004). Historically this species was found in 109 densities of up to 2 individuals $\mathrm{m}^{-2}$ (Hamel et al., 2001), implying that its bioturbation impact on 110 inshore reef habitats is likely to have been substantial.

112 Inshore reef ecosystems are very dynamic environments in which conditions exhibit a large

113 variation of temperature, salinity, turbidity, and wave energy, all of which influence sediment

114 function and sea cucumber behavior (Mercier, Battaglene \& Hamel, 1999; 2000). Initial studies 
115 investigating the ecological roles of sea cucumbers and sediment function have mainly been

116 conducted ex situ or using mesocosms (e.g. Uthicke, 1999). Given the nature of inshore reef

117 ecosystems, in situ studies are required to obtain more realistic results (see Wolkenhauer et al.,

118 2010; Namukose et al., 2016).

119

120 Sedimentary $\mathrm{O}_{2}$ consumption (SOC) and sediment $\mathrm{O}_{2}$ penetration depth (OPD) provide a proxy

121 for the function of sediment as a biocatalytic filter system. SOC reflects the respiration of the

122 entire sedimentary community contained in a core and integrates OM deposited from the

123 overlying water column (Nickell et al., 2003). $\mathrm{O}_{2}$ penetration depth (OPD) determines the

124 REDOX reactions occurring within the sediment, and thus the volume of sediment effectively

125 participating in aerobic OM decomposition (Glud, 2008). Furthermore, sea cucumber feeding

126 can alter grain size distribution through dissolution of calcium carbonate via acidity and

127 potentially abrasion processes in their gut (Hammond, 1981; Schneider et al., 2011). As the

128 composition of sediment grain size influences sediment $\mathrm{O}_{2}$ dynamics (Urumović \& Urumović,

129 2014), changes in grain size distribution caused by sea cucumbers may account for changes in

130 SOC and OPD.

131

132 The current study aimed to understand how the removal of sea cucumbers affects sedimentary

133 function through in situ experimental manipulations of $H$. scabra densities, thus providing

134 information on the poorly understood ecological implications of sea cucumber fisheries. We

135 hypothesized that high densities of $H$. scabra would facilitate the efficient degradation of OM.

136 Thus, in areas with H. scabra, SOC rates were expected to decrease or remain relatively lower,

137 and OPD was expected to increase compared to those areas devoid of $H$. scabra. Finally, 
138 sediment turnover - the amount of sediment ingested by H. scabra - was quantified as a proxy

139 for the bioturbation potential of the animal.

140

141

\section{METHODS}

142

143 Study site

144 The experiment was conducted between August 2015 and February 2016 on an extensive reef

145 flat in front of Natuvu village, Wailevu East District, Vanua Levu, Fiji (16 ${ }^{\circ} 44.940$ 'S

$\left.146179^{\circ} 9.280^{\prime} \mathrm{E}\right)$ (Fig. 1). The reef flat was part of the locally-managed marine area (LMMA) of the

147 local villages. The entire reef flat covered an area of roughly $1.2 \mathrm{~km}^{2}$, and contained a tabu area

148 (periodically harvested closure). This tabu area supported a relatively high density of $H$. scabra

149 compared to the wider region, which was closer to regional reference values (Pakoa et al., 2013).

150 The remoteness of the study site and lack of electricity and infrastructure unfortunately

151 prohibited reliable OM measurements.

152

153 A pilot survey of the site using $100 \mathrm{~m} \times 2 \mathrm{~m}$ belt transects was conducted various times

154 throughout the day and night, and during various tides in order to optimize estimates of the

155 population density, and burying and feeding behavior of $H$. scabra throughout a 24 h cycle.

156

157 Enclosure design and construction

158 Sixteen square plots were demarcated on the reef flat, comprising four treatments: three types of

159 enclosures and one control $\left(\mathrm{n}=4\right.$ treatment $\left.^{-1}\right)$. Treatments included (i) high density (high) (ca.

$160350 \mathrm{~g} \mathrm{~m}^{-2}$ - based on the in situ carrying capacity for H. scabra (Namukose et al., 2016; Lavitra, 
161 Rasolofonirina \& Eeckhaut, 2010; Purcell \& Simutoga, 2008; Battaglene, Evizel \& Ramofafia,

162 1999), (ii) exclusion (exclusion) $\left(0 \mathrm{~g} \mathrm{~m}^{-2}\right.$ - simulating overexploitation), (iii) natural density

163 (natural) (ca. $60 \mathrm{~g} \mathrm{~m}^{-2}$ - determined by a pilot survey at the study site), and (iv) control plots

164 (uncaged control, plots without mesh). Comparing between natural density cages and uncaged

165 control treatments, which had the same density of sea cucumbers, allowed assessing the effect of

166 the presence of mesh cages. Enclosures were stocked with $H$. scabra of length $c a .15 \mathrm{~cm}$, which

167 equates to $c a .200 \mathrm{~g}$ ind $^{-1}$, as this was the most common length of $H$. scabra in the general area

168 where enclosures were situated. Stocking densities were monitored six days per week and

169 enclosures restocked if necessary. Ca. $15 \mathrm{H}$. scabra were maintained in high-density enclosures

170 and approximately three in natural-density enclosures. All animals used to stock enclosures were

171 collected from beyond $500 \mathrm{~m}$ outside the study site.

172

173 The lengths and weights of $H$. scabra were recorded following similar methods used by Seeto

174 (1994) and Al-Rashdi et al. (2007). H. scabra individuals were removed from the water and

175 allowed to initially contract and expel water, which happened almost immediately following

176 handling $(<3 \mathrm{~s})$. The animal's length was recorded from anus to mouth by placing a ruler along

177 its ventral surface. All measurements were recorded to the nearest centimeter. The specimens

178 were then placed into containers filled with water from the site. Water in the containers was

179 continuously exchanged to reduce stress on the animals. All $H$. scabra of the same length were

180 kept together in containers. Following each collection, the animals were taken ashore and

181 weighed on a digital scale $( \pm 0.02 \mathrm{~g})$ to the nearest gram. Time from initial capture to weighing

182 was no longer than $1 \mathrm{~h}$. Individuals were allowed to contract and expel water before being

183 weighed, as described above. Following weighing, all sea cucumbers were released back to the 
184 site.

185

186 Enclosures (3 x 3 m) were designed according to recommendations by Miller \& Gaylord (2007)

187 in order to minimise cage effects. Each enclosure was constructed using eight $1.5 \mathrm{~m}$ pieces of 16

$188 \mathrm{~mm}$ steel re-bar driven vertically into the sediment, with walls comprised of high-density

189 polyethylene diamond mesh with a $40 \mathrm{~mm}$ aperture. Re-bars were woven through the mesh and

190 driven $c a .20 \mathrm{~cm}$ into the sediment, leaving $c a .80 \mathrm{~cm}$ of mesh exposed. Enclosure construction

191 was completed on the second week of September following initial measurements $(\mathrm{T}=0)$.

192

193 Enclosures were monitored for any signs of damage, disturbance, or need for restocking once a

194 day - at low tide - six days per week (the community did not allow any work on Sunday for

195 religious reasons). All animals used to restock enclosures were collected from the immediate

196 area around each respective enclosure. The weather was monitored throughout the course of the

197 study using national and regional weather reports (www.met.gov.fj), and anecdotal reports from

198 villagers at the study site.

199

200 Primary sediment sampling was conducted during the first week of each month. A plot from each

201 treatment (i.e. high, exclusion, natural, and uncaged control) was randomly selected for 202 sediment sampling each day. Sampling generally took place between $0700 \mathrm{~h}$ and $0900 \mathrm{~h}$, which 203 coincided with the rising tide, as dissolved $\mathrm{O}_{2}$ levels during this time were at their optimum for 204 SOC measurements.

206 Grain size distribution 
207 Sediment samples $\left(\mathrm{n}=3\right.$ treatment $\left.^{-1}\right)$ were collected using a corer made from a clear $50 \mathrm{ml}$ 208 syringe (core depth $=c a .30 \mathrm{~mm}$, diameter $=c a .30 \mathrm{~mm}$ ). Sediment cores for each plot were 209 transferred into individual airtight containers. Sediment cores were washed out of their 210 containers onto a dish using freshwater, then placed in a dry oven at $70^{\circ} \mathrm{C}$ for $c a .12 \mathrm{~h}$. Dry

211 sediment samples were weighed and transferred to the top of a sieve column $(\geq 2000,1000,500$,

$212250,125, \leq 125 \mu \mathrm{m})$ attached to a sieve shaker. The sieve column was shaken for seven minutes,

213 and the contents of each sieve then weighed using a ViBRA analytical balance ( $\pm 0.02 \mathrm{~g})$. If salt

214 in the sediment samples were to influence results, it is likely the smallest grain size fractions 215 would have been affected.

217 Oxygen penetration depth

218 Sediment cores from the study site exhibited a clear anoxic layer characterized by consistently

219 dark sediment, which indicates sulphate reduction to hydrogen sulphide by sulphate-reducing

220 bacteria (Castro \& Huber, 2012). Therefore it was possible to determine OPD visually by 221 measuring the distance from the top of the core to the black layer within sediment cores $(n=3$

222 treatment $^{-1}$, to a depth $\geq 3 \mathrm{~cm}$ ) collected in clear $50 \mathrm{ml}$ syringes, following methods adapted from

223 Nilsson \& Rosenberg (2000). OPD was only measured from $\mathrm{T}=2$ onwards, due to time 224 constraints during $\mathrm{T}=0$ and the initial method trialed during $\mathrm{T}=1$ being unsuitable.

226 Sedimentary oxygen consumption

$227 \mathrm{O}_{2}$ consumption of sediments is driven by respiration of benthic organisms, microbially228 mediated oxidation of OM, and reduced inorganic metabolites (Kristensen, 2000), therefore SOC 229 can indicate OM input and degradation at a local level. In situ determination of SOC was based 
230 on methods used by Ford et al. (2017). Sediment cores $\left(10 \mathrm{~cm}^{3}\right)$ were collected from enclosures

231 using cut $50 \mathrm{ml}$ syringes and transferred immediately to $160 \mathrm{ml}$ glass incubation chambers.

232 Chambers were subsequently filled with undisturbed water from the overlying water column

$233\left(\mathrm{n}=4\right.$ treatments enclosure $\left.{ }^{-1}\right) . \mathrm{O}_{2}$ concentration, salinity, and temperature were measured using an

$234 \mathrm{O}_{2}$ optode sensor and conductivity probe (MultiLine ${ }^{\circledR}$ IDS 3430, WTW GmbH, Weilheim,

235 Germany, accuracy: $\pm 0.5 \%$ of measured value). $\mathrm{O}_{2}$ saturation was consistently between 70 -

$236120 \%$ at initial measurements. Chambers were sealed airtight before being placed into opaque

237 bags and then placed in an icebox filled with water from the site to maintain a consistent

238 temperature and to ensure light was excluded. After $c a .1 \mathrm{~h}$ incubation, chambers were collected

239 and $\mathrm{O}_{2}$ concentration was re-measured. The exact duration (minutes) of each incubation was

240 recorded. Salinity and seawater temperature within the chambers were re-measured to ensure

241 consistency throughout measurements. Controls $\left(n=3\right.$ enclosure $\left.{ }^{-1}\right)$ contained only undisturbed

242 water from our site, allowing us to account for microbial activity in the overlying water column.

$243 \mathrm{O}_{2}$ consumption in control chambers was averaged and subtracted from sediment SOC chamber

244 rates. SOC values were calculated into $\mathrm{mmol} \mathrm{O}_{2} \mathrm{~m}^{-2}$ sediment $\mathrm{d}^{-1}$ after accounting for incubation

245 time, vial volume and control measurements.

247 Sediment turnover

248 Daily sediment turnover (proxy for bioturbation) by $H$. scabra was calculated by assuming the

249 quantity of defecated sediment was equal to the quantity of ingested sediment (Uthicke, 1999).

$250 H$. scabra between lengths of $8-16 \mathrm{~cm}(\mathrm{n}=27$, mean length $=13 \mathrm{~cm} \pm 0.22$ SE; mean mass $=145$

$251 \mathrm{~g} \pm 6.27 \mathrm{SE}$ ) were selected for this parameter as they represent the most abundant size class

252 across the entire reef flat and were found in the three most common habitats outside the 
253 enclosures: sand $(\mathrm{n}=17)$, Halodule spp. bed $(\mathrm{n}=6)$, and Syringodium spp. bed $(\mathrm{n}=4)($ Lee, 2016).

254 Data were collected at flood and ebb tide during both night and day over the course of two weeks

255 in January $2016(0800 \mathrm{~h}-2100 \mathrm{~h}$, and random checks for feeding behavior between $0100 \mathrm{~h}-$

$2560500 \mathrm{~h}$ ). The methodology for this experiment was adapted from a similar study by Uthicke 257 (1999).

258

259 Sediment defecated was quantified from trails of faeces behind H. scabra. Markers were driven

260 vertically into the sediment at a standardised distance $(c a .1 \mathrm{~cm})$ behind the posterior end of the

261 animal. Approximately every hour (for $4 \mathrm{~h}$ ) the animal was relocated, and an additional marker

262 placed at its posterior end. The animal's length and weight were recorded, and time was noted

263 each time a marker was placed. Six pellets per animal were collected in individual vials during

264 the four hours that the animal was monitored, and the number of pellets between each marker

265 was counted. Sediment pellets were placed in a dry oven at $70^{\circ} \mathrm{C}$ for approximately $12 \mathrm{~h}$ before

266 weighing on an analytical balance $( \pm 0.02 \mathrm{~g})$. Bulk density of sediment at the study site was

267 calculated by comparing the volume of sediment cores to the dry weight of sediment contained 268 within.

269

270 Data analysis

271 Grain size analysis, textural classifications and distribution of sediments were carried out in R

272 using the gran.stats function (rysgran package - Gilbert et al., 2014) based on methods and

273 verbal classifications by Folk \& Ward (1957). Differences in skewness, kurtosis, and median

274 grain size were tested using the aov function in R (built-in function; R Core Team, 2016). The

275 effect of treatment and time on SOC and OPD data were analysed using repeated-measures 
276 analyses of variances using the aov function in R (built-in function; R Core Team, 2016),

277 followed by post-hoc students t-tests or Mann Whitney-Wilcox $\mathrm{U}$ test (t.test and

278 pairwise.wilcox.test - built-in function; R Core Team, 2016) as appropriate. All multiple

279 comparison post-hoc tests were performed with Bonferroni correction. Paired tests were used to

280 compare a treatment over time, whereas non-paired tests were applied to compare among

281 treatments for a single sample date. Data were tested for normality using a Shapiro-Wilk test and

282 a Quantile-Quantile plot of the residuals, and for homogeneity of variances using a Levene's test

283 (leveneTest - car package; Fox \& Weiberg, 2011). SOC and OPD data were transformed ( $\log 10)$

284 using $\mathrm{R}$ in order to meet assumptions of normality. If these data did not meet the assumptions

285 then the non-parametric Mann Whitney-Wilcox U test (pairwise.wilcox.test-built-in function; $\mathrm{R}$

286 Core Team, 2016) was used. Uncaged control and natural treatments were tested against each

287 other for significant differences at each sampling date; if no significant differences were found 288 then high treatment was compared to exclusion treatment, and natural was compared to 289 exclusion and high treatments.

\section{RESULTS}

292 As indicated above, primary sediment sampling was conducted during the first week of each

293 month. Sampling began in September $2015(\mathrm{~T}=0)$ and continued each month until February 2016

$294(\mathrm{~T}=5)$. As enclosures were checked daily and restocked if necessary to maintain stocking 295 densities, the effect of loss of $H$. scabra between restocking was deemed minimal; overall, 296 restocking was in the range of two to three animals in the high treatment enclosures and one to 297 two animals in cages of the natural treatment. H. scabra would occasionally have to be removed 298 from exclusion treatment enclosures. 


\section{Environmental parameters}

301 Water temperature as quantified during initial SOC measurements showed a steady increase

302 between September $\left(\mathrm{T}=0 ; 23.8^{\circ} \mathrm{C} \pm 0.23\right.$ mean $\left.\pm \mathrm{SE}\right)$ and December $2015\left(\mathrm{~T}=3 ; 26.6^{\circ} \mathrm{C} \pm 0.19\right)$,

303 followed by a severe increase between December 2015 and February $2016\left(\mathrm{~T}=5 ; 31.2^{\circ} \mathrm{C} \pm 0.07\right)$

304 (Fig. 2a). Heavy rain 10 days prior to sampling in November (T=2; Fig. 2c) caused coastal

305 flooding, and a tropical depression (Tropical Disturbance 05F; Fiji Meteorological Service, 306 2015) 5 days prior to sampling in January (T=4; Fig. 2c) caused coastal flooding and storm surge 307 at the site.

308

309 Grain size distribution

310 Throughout the course of the study within all treatments, mean skewness was between 0.01 and

3110.07 , i.e. near symmetrical, and mean kurtosis was between 0.88 and 0.95 , i.e. approximately

312 mesokurtic. Therefore, grain size distribution was approximately normal. Prior to the onset of the

313 experiment $(\mathrm{T}=0)$ there were neither significant differences in grain size fractions between

314 controls (uncaged control vs. natural treatment) nor experimental treatments (high vs. exclusion)

315 (ANOVA; $p>0.05$ ). The uncaged control and natural treatments remained consistent between

$316 \mathrm{~T}=0$ and $\mathrm{T}=3$ (ANOVA; $p=>0.05$ ). Over the same time period the high treatment did exhibit two

317 trends, though they are contradictory and neither was significant (ANOVA; $p>0.05$ ). First, there

318 was an increase in median grain size from $0.91 \pm 0.09$ phi (mean $\pm \mathrm{SE}$ ) to $1.07 \pm 0.06$ phi (mean

$319 \pm \mathrm{SE}$ ), and second, skewness tended to decrease from $0.04 \pm 0.03$ (mean $\pm \mathrm{SE}$ ) at $\mathrm{T}=0$ to $0.01 \pm$

3200.03 (mean $\pm \mathrm{SE}$ ) at $\mathrm{T}=3$. Despite storm surge affecting the study site five days prior to $\mathrm{T}=4$,

321 there were no significant differences between treatments at $\mathrm{T}=4$ and $\mathrm{T}=5$ (ANOVA; $p>0.05$ ). 
322 Changes to grain size distribution between $\mathrm{T}=3$ and $\mathrm{T}=4$ were not considered, as the storm surge

323 between these sampling events had visibly shifted sediments.

324

325 Oxygen penetration depth

326 The interaction of treatment and time had a significant effect on OPD (Repeated measures

327 ANOVA; $F(9,116), p=0.02)$. OPD measurements began at $\mathrm{T}=2$ of the experiment. Initial $(\mathrm{T}=2)$

328 OPD were similar between treatments and controls (Mann-Whitney U-test; $p>0.05$ ). By $\mathrm{T}=3$ the

329 only significant change was an increased OPD in high treatment enclosures (Mann-Whitney U-

330 test; $p=0.03$ ). The exclusion treatment remained consistent (Mann-Whitney U-test; $p=0.37$ )

331 between $\mathrm{T}=2$ and $\mathrm{T}=3$. A distinctly different pattern emerged at $\mathrm{T}=5$. Whilst high treatment

332 enclosures returned to their earlier state ( $\mathrm{T}=5$ vs. $\mathrm{T}=2$; $\mathrm{U}$-test, $p=1$ ), $\mathrm{OPD}$ in sediment from

333 exclusion treatment enclosures decreased from $32 \mathrm{~mm} \pm 3$ at $\mathrm{T}=3$ to $12 \mathrm{~mm} \pm 2$ (mean $\pm \mathrm{SE}$ ) at

$334 \mathrm{~T}=5$, exhibiting a $63 \%$ reduction and resulting in a highly significant difference between

335 treatments (Mann-Whitney U-test; $p<0.01$ ). While natural and uncaged control varied over the

336 course of the entire study (Fig. 2b), there were no significant differences between natural and

337 uncaged control at any individual sampling date.

338

339 Sedimentary oxygen consumption

340 The interaction of treatment and time had a significant effect on SOC (Repeated measures

341 ANOVA; $F(15,360), p<0.01)$. Between $\mathrm{T}=0$ and $\mathrm{T}=1$, $\mathrm{SOC}$ in exclusion treatment areas initially

342 increased almost two-fold from $43.03 \mathrm{mmol} \mathrm{O}_{2} \mathrm{~m}^{-2}$ day $^{-1} \pm 4.59$ to $75.96 \mathrm{mmol} \mathrm{O}_{2} \mathrm{~m}^{-2}$ day $^{-1} \pm$

3434.69 (Mann-Whitney U-test; $p<0.01$, Fig. 2c). Over the same time period, high treatment SOC

344 rates remained consistent (Mann-Whitney U-test, $p=0.74$ ). Sediment in exclusion treatment areas 
345 had a noticeably higher SOC than high treatment areas at T=1 and T=3 (Mann-Whitney U-test;

$346 p<0.01$, at both $\mathrm{T}=1$ and $\mathrm{T}=3$ ). Apart from an initially higher SOC rate in the natural compared

347 with the uncaged control treatment at $\mathrm{T}=0$ (Mann-Whitney U-test; $p<0.01$ ), there were no

348 differences throughout the experimental period. Uncaged control increased significantly from

$349 \mathrm{~T}=0$ to $\mathrm{T}=1$ (Mann-Whitney U-test, $p<0.01$ ), while natural did not over this time period (Mann-

350 Whitney U-test, $p>0.05$ ). Natural and high treatments only showed a significant difference

351 (Mann-Whitney U-test, $p<0.01$ ) at $\mathrm{T}=3$, while natural and exclusion treatments only exhibited

352 significant differences at $\mathrm{T}=0$ and $\mathrm{T}=1$ (Mann-Whitney U-test, $p=0.02$ and $p<0.01$, respectively).

353

354 Sediment turnover

355 On average each animal produced 26 sediment pellets $\mathrm{h}^{-1} \pm 2$, which had a mass of $0.36 \mathrm{~g} \pm 0.01$.

356 Observations of $H$. scabra at the study site showed this species actively fed for $10 \mathrm{~h} \mathrm{day}^{-1}$ during

357 daylight hours $(0600-1800 \mathrm{~h})$ and were inactive for $14 \mathrm{~h} \mathrm{day}^{-1} ; H$. scabra at the site generally

358 remained buried during low tide. During daylight hours $H$. scabra were found at a density of 31

359 ind. $100 \mathrm{~m}^{-2}$; this equates to $372,000 \mathrm{H}$. scabra on Natuvu's ca. $1.2 \mathrm{~km}^{2}$ reef flat. Bulk density of

360 sediment at the site was $0.83 \mathrm{~g} \mathrm{~cm}^{-3} \pm 0.01$. After incorporating these findings, calculations

361 (Table 1) showed that the H. scabra population on Natuvu's reef flat had the potential to rework

$36210,590.84 \mathrm{~kg}$ sediment dry weight $1000 \mathrm{~m}^{-2} \mathrm{y}^{-1}$. Given the bulk density of sediment at the site,

363 the upper $5 \mathrm{~mm}$ of sediment in an area of $1000 \mathrm{~m}^{2}$ would weigh $4150 \mathrm{~kg}$. Assuming sea

364 cucumbers consume sediment to a depth of $5 \mathrm{~mm}$, which is based on observations noted in

365 Uthicke (1999), the estimated population of H. scabra in $1000 \mathrm{~m}^{2}$ has the potential to rework the

366 upper $5 \mathrm{~mm}$ of sediment approximately two and a half times a year. 


\section{DISCUSSION}

371 The current study explored the impact of holothurian removal on sedimentary function in a

372 unique in situ setting. Despite the considerable 'background noise' from inherent and

373 uncontrollable factors such as waves, wind, currents and marine benthos, several parameters

374 provided clear evidence that overharvesting of sea cucumbers has a potentially strong effect on

375 the ability of sediment to function as a biocatalytic filter system. The estimated rates of sediment

376 turnover observed here for Holothuria scabra alone are substantial, and are more than twice the

377 turnover recorded for a mixed population of $H$. atra and Stichopus chlorontus (4600 kg dry wt

$378 \mathrm{yr}^{-1} 1000 \mathrm{~m}^{-2}$ ), which was estimated to be equivalent to turning over the upper $5 \mathrm{~mm}$ of sediment

379 in that area annually (Uthicke, 1999).

380

381 Grain size selectivity has not been conclusively demonstrated for H. scabra (e.g. Wiedmeyer,

382 1982; Tsiresy et al., 2011). However, within the current study, changes to grain size composition

383 in areas of high $H$. scabra densities and the lack of any changes in their absence indicate that $H$.

384 scabra are selective to certain grain sizes. This suggests that when sea cucumbers are present on

385 inshore reef flats in high densities, they play a key role in the physical reworking and change of

386 sediment structure in marine ecosystems. Based on the observed non-significant trends, a higher

387 number of samples are suggested for future work. Several sea cucumber species are able to

388 change sediment grain size through dissolution of calcium carbonate via acidity, and potentially

389 abrasion processes, in their gut (Hammond, 1981; Schneider et al., 2011). 
391 Throughout the study SOC rates and OPD exhibited a 'buffered' response in high treatment

392 enclosures compared to exclusion enclosures, where they exhibited several large fluctuations.

393 This buffered response was characterized by a predictable pattern with relatively low amplitude

394 changes. Higher SOC rates in the exclusion treatment were consistent with findings by Nickell et

395 al. (2003); these higher SOC rates were likely driven by the increased respiration of benthic

396 fauna, microbially-mediated oxygenation of OM, and reduced inorganic metabolites (Kristensen,

397 2000; Nickell et al., 2003). Deviations from this trend occurred at $\mathrm{T}=2$ and $\mathrm{T}=4$, following 398 coastal flooding ten days prior to $\mathrm{T}=2$, and storm surge and coastal flooding five days prior to

$399 \mathrm{~T}=4$. Differences between the $\mathrm{T}=0$ measurements and the strong increase in the uncaged control

400 between $\mathrm{T}=0$ and $\mathrm{T}=1$, compared to an absence of changes in the natural treatment over the 401 same time, could be attributed to sampling during different tides, which was rectified for later 402 time-points. Sea cucumbers actively feed on OM, thus reducing its concentration within the 403 sediment (e.g. Uthicke \& Karez, 1999; Wolkenhauer et al., 2010). Thus, there should be a higher 404 OM concentration in the sediment of the exclusion treatment compared with that of the high 405 treatment. Relatively higher OM concentrations facilitate increased microbial abundance and 406 activity (MacTavish et al., 2012), in line with the observed higher SOC rates in exclusion 407 treatment enclosures. Similarly, coastal flooding (observed at the study site ten days prior to $\mathrm{T}=2$ 408 and five days prior to $\mathrm{T}=4$ ) likely delivered a strong OM-'pulse' onto the reef flat (Briand et al., 409 2015), explaining the elevated SOC rates even in high treatment enclosures following flooding 410 (Fig. 2c).

411

412 The buffering capacity provided by high sea cucumber densities is likely due to the effect of the 413 animals' feeding, excretion, and bioturbation. Feeding by sea cucumbers acts to 'clean' 
414 sediments, whereas the subsequent digestion and excretion of waste products plays an important

415 role in nutrient recycling (Purcell et al., 2016). The recycled nutrients stimulate the growth of

416 benthic microalgal communities (e.g. Uthicke \& Klumpp, 1998; Uthicke, 2001a), which absorb

417 nutrients and produce $\mathrm{O}_{2}$ through photosynthesis (Stockenreiter et al., 2016). Bioturbation

418 increases advective flow into and within the sediment directly through burying, burrowing, and

419 bio-irrigation (Meysman, Middleburg \& Hiep, 2006), and indirectly as it increases bed sediment

420 complexity (bioroughness). Bioroughness creates pressure gradients that can increase advective

421 porewater flow up to seven-fold compared to smooth-bed flows (Thibodeaux \& Boyle, 1987;

422 Huettel \& Gust, 1992), increasing the supply of degradable material and electron acceptors (such

423 as $\mathrm{O}_{2}$ ) to the sediment (Rusch et al., 2006), and thus promoting aerobic degradation. As aerobic

424 degradation of $\mathrm{OM}$ in marine sediments is $c a$. ten times faster than anaerobic degradation

425 (Kristensen, Ahmed \& Devol, 1995; Hulthe, Hulth \& Hall, 1998), sea cucumbers promote the

426 efficient degradation of OM in a closely coupled benthic recycling system.

As grain size distribution showed no significant difference between high and exclusion treatment sediments at $\mathrm{T}=5$, simultaneous changes of OPD are assumed to be caused by the presence of sea cucumbers and not an alteration in sediment structure following storm surge prior to $\mathrm{T}=4$.

431 Exceptionally high temperatures were recorded at $\mathrm{T}=5\left(31.2^{\circ} \mathrm{C} \pm 0.07\right)$ compared with earlier 432 months $\left(\mathrm{T}=0\right.$ to $\mathrm{T}=3 ; 25.74^{\circ} \mathrm{C} \pm 0.16$ ) as a result of the $2015 / 2016 \mathrm{El}$ Niño (Blunden, 2017).

433 High water temperatures recorded at $\mathrm{T}=5$ coincided with the substantial reduction in sediment

434 OPD of exclusion treatment enclosures. Warmer water temperatures induce microbial growth 435 and respiration (Nydahl, Panigrahi \& Wikner, 2013), and the relatively calm conditions for the 436 same time-period resulted in limited wave action and thus limited mixing of bed sediment and 
437 the overlying water column. Both these factors contribute to an increased SOC and a reduced

438 OPD (Kristensen, 2000; Friedrich et al., 2014). The high, natural and uncaged control treatments

439 did not experience a rapid reduction in OPD, despite being subject to the same environmental

440 conditions. The abrupt and significant reduction in OPD during $\mathrm{T}=5$ in the exclusion treatment

441 was likely caused by the combined manifestation of local and global stressors: the removal of sea

442 cucumbers and the coinciding rapid increase in sea surface temperature.

444 Storm surge five days prior to $\mathrm{T}=4$ had visibly shifted and re-suspended a considerable amount

445 of sediment at the study site. This disturbance would have functioned similarly to bioturbation

446 (e.g. by oxygenating sediment and redistributing OM), explaining the significantly decreased

447 SOC rate in exclusion enclosures at $\mathrm{T}=4$ (Fig. 2c). Disturbances such as storms, which are

448 projected to increase in intensity as a consequence of climate change (Emanuel, 2013; IPCC,

449 2014), may thus be able to induce sufficient mixing of bed sediment capable of reducing SOC.

450 However, the same models predict an increase in the severity, frequency, and duration of

451 extreme precipitation events and heat waves (IPCC, 2014). While the global stressor of increased

452 sea surface temperature in the current study had an effect on sediment function in all treatments,

453 the high densities of sea cucumbers in the high treatment were able to buffer such extreme

454 changes, particularly to OPD.

455

456 These results suggest a synergistic interaction between local and global stressors, whereby

457 reductions in bioturbation caused by local overexploitation of a key benthic species (Solan et al., 458 2004) in combination with elevated temperatures led to an amplified effect. As mean sea surface 459 temperatures, warm temperature extremes, and heavy precipitation events are forecast to increase 
460 and occur at higher frequency and intensity (IPCC, 2014), bioturbation becomes increasingly

461 important to maintaining and improving sediment quality. Given the mechanisms of benthic-

462 pelagic coupling (Wild, Tollrian \& Huettel, 2004b), the increased SOC rate and reduced OPD

463 observed in areas void of $H$. scabra could contribute to deoxygenation of the overlying water

464 column. Hypoxia affects the distribution, abundance, diversity and physiological state of benthic

465 communities (Meyer-Reil \& Köster, 2000), and increases the risk of hypoxia-derived mortality

466 for larval stages of several marine organisms (Vaquer-Sunyer \& Duarte, 2008).

467

468 High densities $\left(350 \mathrm{~g} \mathrm{~m}^{-2}\right)$ of the sea cucumber H. scabra seem able to enhance the buffering 469 capacity of sediment to stressors such as increased OM load and anoxia. This finding may have 470 particularly strong implications in shallow restricted bodies of water, which are prone to large 471 temperature variability, such as that of Marovo Lagoon, Solomon Islands. In June 2011, the

472 lagoon experienced a large-scale harmful algal bloom, and its subsequent senescence resulted in 473 large-scale hypoxia-derived mortality (Albert, Dunbabin \& Skinner, 2012). The authors of the 474 report suggest this event was caused in part by an increase in the catchment nutrient pool, and 475 reduced processing of sediment nutrients and oxygenation of sediment following 15 years of 476 extensive overharvest of sea cucumbers, combined with prolonged warm and calm weather 477 conditions (Albert et al., 2011). As the frequency and severity of record high global temperatures 478 and El Niño events are projected to increase with climate change (Cai et al., 2014; Blunden, 479 2017), and coastal waters are becoming increasingly eutrophic (Fabricius, 2005), events such as 480 that reported for Marovo Lagoon may become more frequent. As such, the role sea cucumbers 481 play in the bioturbation of inshore sediment becomes increasingly essential to the buffering 482 capacity of tropical coastal marine ecosystems. 


\section{CONCLUSION}

485

486 This study builds upon previous work investigating the ecosystem role of sea cucumbers. 487 Sandfish (H. scabra) are shown to play a demonstrable function in the role of sediment as a 488 biocatalytic filter system. The combination of global stressors such as elevated sea surface 489 temperatures and the local stressor of sea cucumber removal is of particular concern, as our 490 results suggest potential synergisms resulting in an amplified effect. A consequence of the 491 extensive overexploitation of sea cucumbers is that ecosystem functions and services offered by 492 coastal marine environments in which these animals have been removed is likely compromised. 493 These changes will leave coastal human communities increasingly vulnerable, particularly those 494 of small Pacific islands that rely heavily upon such ecosystem services for their livelihoods and 495 food security. We recommend that management should maintain moderate (in this study $60 \mathrm{~g} \mathrm{~m}^{-}$ $\left.496{ }^{2}\right)$ to high densities $\left(350 \mathrm{~g} \mathrm{~m}^{-2}\right)$ of sea cucumbers within reef ecosystems. Such densities should 497 allow sea cucumbers to fulfil their role in maintaining sediment function at a scale that has a 498 measurable impact.

499

\section{ACKNOWLEDGEMENTS}

501

502 We thank the Leibniz Centre for Tropical Marine Research (ZMT), Wildlife Conservation 503 Society, University of Bremen, and University of the South Pacific for supporting field and

504 laboratory work. We would also like to thank Dr. Steven Purcell for comments that helped to 
505 improve this manuscript. Finally, vinaka vakalevu to the people of Natuvu village for allowing

506 this study within their traditional fishing ground.

507

508 Parts of this work have been published in a non-peer reviewed report (Lee et al., 2017) and as an

MSc thesis (Lee, 2016).

510

\section{REFERENCES}

512

513

514

515

516

517

518

519

520

521

522

523

524

525

526

527

528

529

530

531

532

533

534

535

536

537

538

539

540

541

542

543

Albert S, Dunbabin M, Skinner M. 2012. Benthic Shift in a Solomon Island's lagoon: corals to cyanobacteria. Proceedings of the $12^{\text {th }}$ International Coral Reef Symposium, Cairns, Australia, 9-13 July 2012.

Albert S, Grinham A, Dunbabin M, Bird B, Moore BR, Jimuru M, Kwatelae A, Skinner M. 2011. Preliminary assessment of a large fish kill in Marovo Lagoon, Solomon Islands. The University of Queensland. 1-21

Al-Rashdi KM, Claereboudt MR, Al-Busaidi SS. 2007. Density and Size Distribution of the Sea Cucumber, Holothuria scabra (Jaeger, 1935), at Six Exploited Sites in Mahout Bay, Sultanate of Oman. Agricultural and Marine Sciences. 12: 43-51.

Battaglene SC, Evizel SJ, Ramofafia C. 1999. Survival and growth of cultured juvenile sea cucumbers, Holothuria scabra. Aquaculture 178:293-322. DOI: 10.1016/S00448486(99)00130-1

Blunden J. 2017. How unusual is 2016's record-temperature three-peat, and will the hot streak continue in 2017. NOAA. Available at https://www.climate.gov/newsfeatures/blogs/beyond-data/how-unusual-2016s-record-temperature-three-peat-and-willhot-streak (accessed 26 January 2017).

Briand MJ, Bonnet X, Goiran C, Guillou G, Letourneur Y. 2015. Major Sources of Organic Matter in a Complex Coral Reef Lagoon: Identification from Isotopic Signatures $(\delta 13 \mathrm{C}$ and $\delta 15 \mathrm{~N})$. PLoS One 10, e0131555. DOI: 10.1371/journal.pone.0131555

Cai W, Borlace S, Lengaigne M, van Rensch P, Collins, M, Vecchi G, Timmermann A, Santoso A, McPhaden MJ, Wu L, England MH, Wang G, Guilyardi E, Jin F. 2014. Increasing frequency of extreme El Niño events due to greenhouse warming. National Climate Change 5:1-6. DOI: $10.1038 /$ nclimate2100

Castro P, Huber M. 2012. Marine Biology. McGraw-Hill Education; 9 edition. ISBN: 0073524204

Coleman FC, Williams SL. 2002. Overexploiting marine ecosystem engineers: Potential consequences for biodiversity. Trends in Ecology and Evolution 17:40-44. DOI: 10.1016/S0169-5347(01)02330-8

Conservation International. 2008. Economic Values of Coral Reefs, Mangroves, and Seagrasses: A Global Compilation. Center for Applied Biodiversity Science, Conservation International, Arlington, VA, USA.

D’Angelo C, Wiedenmann J. 2014. Impacts of nutrient enrichment on coral reefs: New 
544

545

546

547

548

549

550

551

552

553

554

555

556

557

558

559

560

561

562

563

564

565

566

567

568

569

570

571

572

573

574

575

576

577

578

579

580

581

582

583

584

585

586

587

588

589

perspectives and implications for coastal management and reef survival. Current Opinion in Environmental Sustainability 7: 82-93. DOI: 10.1016/j.cosust.2013.11.029

Emanuel KA. 2013. Downscaling CMIP5 climate models shows increased tropical cyclone activity over the 21st century. Proceedings of the National Academy of Sciences of the United States of America 110: 12219-12224. DOI: 10.1073/pnas. 1301293110

Fabricius KE. 2005. Effects of terrestrial runoff on the ecology of corals and coral reefs: Review and synthesis. Marine Pollution Bulletin 50: 125-146. DOI:

10.1016/j.marpolbul.2004.11.028

Fiji Meteorological Service. 2015. Gale Warning 024, 29 December 2015.

Fox J, Weisberg S. 2011. An $\{\mathrm{R}\}$ Companion to Applied Regression, Second Edition. Thousand Oaks CA: Sage. Available at http://socserv.socsci.mcmaster.ca/jfox/Books/Companion

Folk RL, Ward WC. 1957. Brazor river bar: A study in the signficance of grain size parameters. Journal pf Sediment Petrology 27: 3-27.

Ford AK, Van Hoytema N, Moore BR, Pandihau L, Wild C, Ferse SCA. 2017. High sedimentary oxygen consumption indicates that sewage input from small islands drives benthic community shifts on overfished reefs. Environmental Conservation 1-7. DOI: 10.1017/S0376892917000054

Friedman K, Eriksson H, Tardy E, Pakoa K. 2011. Management of sea cucumber stocks: patterns of vulnerability and recovery of sea cucumber stocks impacted by fishing. Fish and Fisheries 12: 75-93. DOI: 10.1111/j.1467-2979.2010.00384.x

Friedman K, Kronen M, Vunisea A, Pinca S, Pakoa K, Magron F, Chapman L, Sauni S, Vigliola L, Tardy E, Labrosse P. 2009. Pacific Regional Oceanic and Coastal Fisheries Development Programme. Fiji Islands Country Report: Profiles and Results from Survey Work at Dromuna, Muaivuso, Mali, and Lakeba (September to November 2002, April to June 2003, June to July 2007, and February 2009). Secretariat of the Pacific Community.

Friedrich J, Janssen F, Aleynik D, Bange HW, Boltacheva N, Çagatay MN, Dale AW, Etiope G, Erdem Z, Geraga M, Gilli A, Gomoiu MT, Hall POJ, Hansson D, He Y, Holtappels M, Kirf MK, Kononets M, Konovalov S, Lichtschlag A, Livingstone DM, Marinaro G, Mazlumyan S, Naeher S, North RP, Papatheodorou G, Pfannkuche O, Prien R, Rehder G, Schubert CJ, Soltwedel T, Sommer S, Stahl H, Stanev EV, Teaca A, Tengberg A, Waldmann C, Wehrli B, Wenzhöfer F. 2014. Investigating hypoxia in aquatic environments: Diverse approaches to addressing a complex phenomenon. Biogeosciences 11:1215-1259. DOI: 10.5194/bg-111215-2014

Gilbert ER, de Camargo MG, Sandrini-Neto L. 2014. rysgran: Grain size analysis, textural classifications and distribution of unconsolidated sediments. R package version 2.1.0. Available at https://CRAN.R-project.org/package=rysgran

Glud RN. 2008. Oxygen dynamics of marine sediments. Marine Biology Research 4:243-289. DOI: $10.1080 / 17451000801888726$

Haas A, Al-Zibdah M, Wild C. 2009. Effect of inorganic and organic nutrient addition on coralalgae assemblages from the Northern Red Sea. Journal of Experimental Marine Biology and Ecology 380:99-105. DOI: 10.1016/j.jembe.2009.09.005

Halpern BS, Walbridge S, Selkoe KA, Kappel CV, Micheli F, D'Agrosa C, Bruno JF, Casey KS, Ebert C, Fox HE, Fujita R, Heinemann D, Lenihan HS, Madin EMP, Perry MT, Selig ER, Spalding M, Steneck R, Watson R. 2008. A Global Map of Human Impact on Marine Ecosystems. Science 319(5865): 948-952. DOI: 10.1126/science.1149345

Hamel JF, Conand C, Pawson D, Mercier A. 2001. The Sea Cucumber Holothuria scabra 
590

591

592

593

594

595

596

597

598

599

600

601

602

603

604

605

606

607

608

609

610

611

612

613

614

615

616

617

618

619

620

621

622

623

624

625

626

627

628

629

630

631

632

633

634

635

(Holothuroidea: Echinodermata): Its Biology and Exploitation as Beche-de-Mer. Advances in Marine Biology 41:130-202. DOI: 10.1016/S0065-2881(01)41003-0

Hamilton R, Lokani P. 2011. Severely overfished sea cucumbers in the Autonomous Region of Bougainville. SPC Beche-de-mer Information Bulletin 31:12-16.

Hammond LS. 1981. An analysis of grain size modification in biogenic carbonate sediments by deposit-feeding holothurians and echinoids (Echinodermata). Limnology and Oceanography. 26:898-907. DOI: 10.4319/1o.1981.26.5.0898

Huettel M, Gust G. 1992. Impact of bioroughness on interfacial solute exchange in permeable sediments. Marine Ecology Progress Series 89:253-267. DOI: 10.3354/meps089253

Huettel M, Wild C, Gonelli S. 2006. Mucus trap in coral reefs: formation and temporal evolution of particle aggregates caused by coral mucus. Marine Ecology Progress Series 307: 69-84.

Hulthe G, Hulth S, Hall POJ. 1998. Effect of oxygen on degradation rate of refractory and labile organic matter in continental margin sediments. Geochimica et Cosmochimica Acta 62: 1319-1328. DOI: 10.1016/S0016-7037(98)00044-1

IPCC. 2014. Climate Change 2014: Synthesis Report. Contribution of Working Groups I, II and III to the Fifth Assessment Report of the Intergovernmental Panel on Climate Change [Core Writing Team, R.K. Pachauri and L.A. Meyer (eds.)]. IPCC, Geneva, Switzerland, 151.

Jaeger GF. 1833. De Holothuriis. Turici, 1-40.

Kristensen E. 2000. Organic matter diagenesis at the oxic / anoxic interface in coastal marine sediments, with emphasis on the role of burrowing animals. Hydrobiologia 462:1-24. DOI: 10.1023/A

Kristensen E, Ahmed SI, Devol AH. 1995. Aerobic and anaerobic decomposition of organic matter in marine sediment: Which is fastest? Water 40:1430-1437. DOI:

10.4319/lo.1995.40.8.1430

Lavitra T, Rasolofonirina R, Eeckhaut I. 2010. The Effect of Sediment Quality and Stocking Density on Survival and Growth of the Sea Cucumber Holothuria scabra Reared in Nursery Ponds and Sea Pens. Western Indian Ocean Journal of Marine Science 9:153-164.

Lee S. 2016. Sedimentary Response to Sea Cucumber (Holothuria scabra) Removal: insights from experimental manipulations on a Fijian reef flat. MSc Thesis, University of Bremen. DOI: 10.13140/RG.2.2.13965.44004

Lee S, Ferse S, Ford A, Wild C, Mangubhai S. 2017. Effect of sea cucumber density on the health of reef-flat sediments. In: S. Mangubhai, W. Lalavanua and S.W. Purcell (eds.). Fiji's Sea Cucumber Fishery: Advances in Science for Improved Management. Wildlife Conservation Society. Report No. 01/17. Suva, Fiji. 54-61.

Levin L, Ekau W, Gooday AJ, Jorissen F, Middelburg JJ, Naqvi SW, Neira C, Rabalais NN, Zhang J. 2009. Effects of natural and human-induced hypoxia on coastal benthos. Biogeosciences 6:2063-2098. DOI: 10.5194/bgd-6-3563-2009

Lohrer AM, Thrush SF, Gibbs MM. 2004. Bioturbators enhance ecosystem function through complex biogeochemical interactions. Nature 431:1092-1095. DOI: 10.1038/nature03042

MacTavish T, Stenton-Dozey J, Vopel K, Savage C. 2012. Deposit-Feeding Sea Cucumbers Enhance Mineralization and Nutrient Cycling in Organically-Enriched Coastal Sediments. PLoS One 7:1-11. DOI: 10.1371/journal.pone.0050031

Mercier A, Battaglene SC, Hamel JF. 1999. Daily burrowing cycle and feeding activity of juvenile sea cucumbers Holothuria scabra in response to environmental factors. Journal of Experimental Marine Biology and Ecology 239:125-156. DOI: 10.1016/S00220981(99)00034-9 
636

637

638

639

640

641

642

643

644

645

646

647

648

649

650

651

652

653

654

655

656

657

658

659

660

661

662

663

664

665

666

667

668

669

670

671

672

673

674

675

676

677

678

679

680

681
Mercier A, Battaglene SC, Hamel JF. 2000. Periodic movement, recruitment and size-related distribution of the sea cucumber Holothuria scabra in Solomon Islands. Hydrobiologia 440:81-100. DOI: 10.1023/A:1004121818691

Meyer-Reil LA, Köster M. 2000. Eutrophication of marine waters: Effects on benthic microbial communities. Marine Pollution Bulletin 41:255-263. DOI: 10.1016/S0025-326X(00)001144

Meysman FJR, Galaktionov OS, Gribsholt B, Middelburg JJ. 2006. Bioirrigation in permeable sediments: Advective pore-water transport induced by burrow ventilation. Limnology and Oceanography 51:142-156. DOI: 10.4319/lo.2006.51.1.0142

Meysman FJR, Middelburg JJ, Heip CHR. 2006. Bioturbation: a fresh look at Darwin's last idea. Trends in Ecology and Evolution 21:688-695. DOI: 10.1016/j.tree.2006.08.002

Miller LP, Gaylord B. 2007. Barriers to flow: The effects of experimental cage structures on water velocities in high-energy subtidal and intertidal environments. Journal of Experimental Marine Biology and Ecology 344:215-228. DOI:

10.1016/j.jembe.2007.01.005

Moberg FF, Folke C. 1999. Ecological goods and services of coral reef ecosystems. Ecological Economics 29:215-233. DOI: 10.1016/S0921-8009(99)00009-9

Namukose M, Msuya FE, Ferse SCA, Slater MJ, Kunzmann A. 2016. Growth performance of the sea cucumber Holothuria scabra and the seaweed Eucheuma denticulatum: integrated mariculture and effects on sediment organic characteristics. Aquaculture Environment Interactions 8:179-189. DOI: 10.3354/aei00172

Nickell LA, Black KD, Hughes DJ, Overnell J, Brand T, Nickell TD, Breuer E, Harvey SM. 2003. Bioturbation, sediment fluxes and benthic community structure around a salmon cage farm in Loch Creran, Scotland. Journal of Experimental Marine Biology and Ecology 285:221-233. DOI: 10.1016/S0022-0981(02)00529-4

Nilsson HC, Rosenberg R. 2000. Succession in marine benthic habitats and fauna. Marine Ecology 197:139-149.

Nydahl A, Panigrahi S, Wikner J. 2013. Increased microbial activity in a warmer and wetter climate enhances the risk of coastal hypoxia. FEMS Microbiology Ecology 85:338-347. DOI: $10.1111 / 1574-6941.12123$

Pakoa K, Saladrau W, Lalavanua W, Valotu D, Tuinasavusavu I, Sharp M, Bertram I. 2013. The Status of Sea Cucumber Resources and Fisheries Management in Fiji. Secretariat of the Pacific Community (SPC), Noumea. DOI: 10.1071/MU9870232

Poore GCB, Wilson G. 1993. Marine species richness. Nature 361:598-598.

Purcell SW. 2004. Rapid growth and bioturbation activity of the sea cucumber Holothuria scabra in Earthen Ponds. Proceeding of Australasian Aquaculture.

Purcell SW. 2014. Value, Market preferences and trade of beche-de-mer from pacific island sea cucumbers. PLoS One. DOI: 10.1371/journal.pone.0095075.t002

Purcell SW, Conand C, Uthicke S, Byrne M. 2016. Ecological roles of exploited sea cucumbers. Oceanography and Marine Biology - An Annual Review 54:367-386.

Purcell SW, Mercier A, Conand C, Hamel JF, Toral-Granda MV, Lovatelli A, Uthicke, S. 2013. Sea cucumber fisheries: Global analysis of stocks, management measures and drivers of overfishing. Fish and Fisheries 14:34-59. DOI: 10.1111/j.1467-2979.2011.00443.x

Purcell SW, Simutoga M. 2008. Spatio-Temporal and Size-Dependent Variation in the Success of Releasing Cultured Sea Cucumbers in the Wild. Reviews in Fisheries Science 16:204214. DOI: $10.1080 / 10641260701686895$ 
682 R Core Team, 2016. R: A language and environment for statistical computing. R Foundation for

683 Statistical Computing, Vienna, Austria. Available at http://www.R-project.org/.

684

685

686

687

688

689

690

691

692

693

694

695

696

697

698

699

700

701

702

703

704

705

706

707

708

709

710

711

712

713

714

715

716

717

718

719

720

721

722

723

724

725

726

727

Rabalais NN, Turner RE, Díaz RJ, Justić D. 2009. Global change and eutrophication of coastal waters. ICES Journal of Marine Science 66:1528-1537.

Rusch A, Huettel M, Wild C, Reimers CE. 2006. Benthic oxygen consumption and organic matter turnover in organic-poor, permeable shelf sands. Aquatic Geochemistry 12:1-19. DOI: $10.1007 / \mathrm{s} 10498-005-0784-\mathrm{X}$

Schneider K, Silverman J, Woolsey E, Eriksson H, Byrne M, Caldeira K. 2011. Potential influence of sea cucumbers on coral reef $\mathrm{CaCO} 3$ budget: A case study at One Tree Reef. Journal of Geophysical Research: Biogeosciences 116:2-7. DOI: 10.1029/2011JG001755

Seeto J. 1994. The reproductive biology of the sea cucumber Holothuria atra Jaeger, 1833 (Echinodermata: Holothuroidea) in Laucala Bay, Fiji, with notes on its population structure and symbiotic associations.

Skewes T, Dennis D, Burridge C. 2000. Survey of Holothuria scabra (sandfish) on Warrior Reef, Torres Strait, January 2000, CSIRO Marine Research.

Solan M, Cardinale BJ, Downing AL, Engelhardt KAM, Ruesink J.L. 2004. Extinction and Ecosystem Function in the Marine Benthos. Science 306:1177-1180. DOI: 10.1126/science. 1103960

Stockenreiter M, Haupt F, Seppälä J, Tamminen T, Spilling K. 2016. Nutrient uptake and lipid yield in diverse microalgal communities grown in wastewater. Algal Research 15:77-82. DOI: 10.1016/j.algal.2016.02.013

Thibodeaux LJ, Boyle JD. 1987. Bedform-generated convective transport in bottom sediment. Nature. DOI: 10.1038/325341a0

Toral-Granda V, Lovatelli A, Vasconcellos M (eds)., 2008. Sea cucumbers: A global review of fisheries and trade. FAO Fisheries and Aquaculture Technical Paper 317.

Tsiresy G, Pascal B, Plotieau T. 2011. An assessment of Holothuria scabra growth in marine micro-farms in southwestern Madagascar. SPC Beche-de-mer Information Bulletin, 31:1722

Urumović K, Urumović K. 2014. The effective porosity and grain size relations in permeability functions. Hydrology and Earth System Sciences Discussion 11:6675-6714. DOI: 10.5194/hessd-11-6675-2014

Uthicke S. 1999. Sediment bioturbation and impact of feeding activity of Holothuria (Halodeima) atra and Stichopus chloronotus, two sediment feeding holothurians, at Lizard Island, Great Barrier Reef. Bulletin of Marine Science 64:129-141.

Uthicke S. 2001a. Interactions between sediment-feeders and microalgae on coral reefs: Grazing losses versus production enhancement. Marine Ecology Progress Series 210:125-138. DOI: 10.3354/meps 210125

Uthicke S. 2001b. Nutrient regeneration by abundant coral reef holothurians. Journal of Experimental Marine Biology and Ecology 265:153-170. DOI: 10.1016/S00220981(01)00329-XUthicke S, Karez R. 1999. Sediment patch selectivity in tropical sea cucumbers (Holothurioidea: Aspidochirotida) analysed with multiple choice experiments. Journal of Experimental Marine Biology and Ecology 236:69-87. DOI: 10.1016/S00220981(98)00190-7

Uthicke S, Klumpp DW. 1998. Microphytobenthos community production at a near-shore coral reef: Seasonal variation and response to ammonium recycled by holothurians. Marine Ecology Progress Series 169:1-11. DOI: 10.3354/meps 169001 
728

729

730

731

732

733

734

735

736

737

738

739

740

741

742

743

744

Vaquer-Sunyer R, Duarte CM. 2008. Thresholds of hypoxia for marine biodiversity. Proceedings of the National Academy of Sciences of the United States of Americ 105:15452-15457. DOI: $10.1073 /$ pnas.0803833105

Wiedmeyer WL. 1982. Feeding behavior of two tropical holothurians Holothuria (Metriatyla) scabra (Jager 1833) and H. (Halodeima) atra (Jager 1833), from Okinawa, Japan. Proceedings of the 7th International Coral Reef Symposium, Guam, 2: 853-860.

Wild C, Laforsch C, Huettel. 2006. Detection and enumeration of microbial cells within highly porous calcareous reef sands. Marine and Freshwater Research 57:415-420

Wild C, Rasheed M, Werner U, Franke U, Johnstone R, Huettel M. 2004a. Degradation and mineralization of coral mucus in reef environments. Marine Ecology Progress Series 267:159-171. DOI: 10.3354/meps267159

Wild C, Tollrian R, Huettel M. 2004b. Rapid recycling of coral mass-spawning products in permeable reef sediments. Marine Ecology Progress Series 271:159-166. DOI: 10.3354/meps271159Wolkenhauer SM, Uthicke S, Burridge C, Skewes T, Pitcher CR. 2010. The ecological role of Holothuria scabra (Echinodermata: Holothuroidea) within subtropical seagrass beds. Journal of the Marine Biological Association of the United Kingdom 90:215-223. 
Figure 1

Map of the study site.

Location of Wailevu East District, Vanua Levu, Fiji (a), and the location of the study site (Natuvu) as indicated by a triangle in Panel $b$.

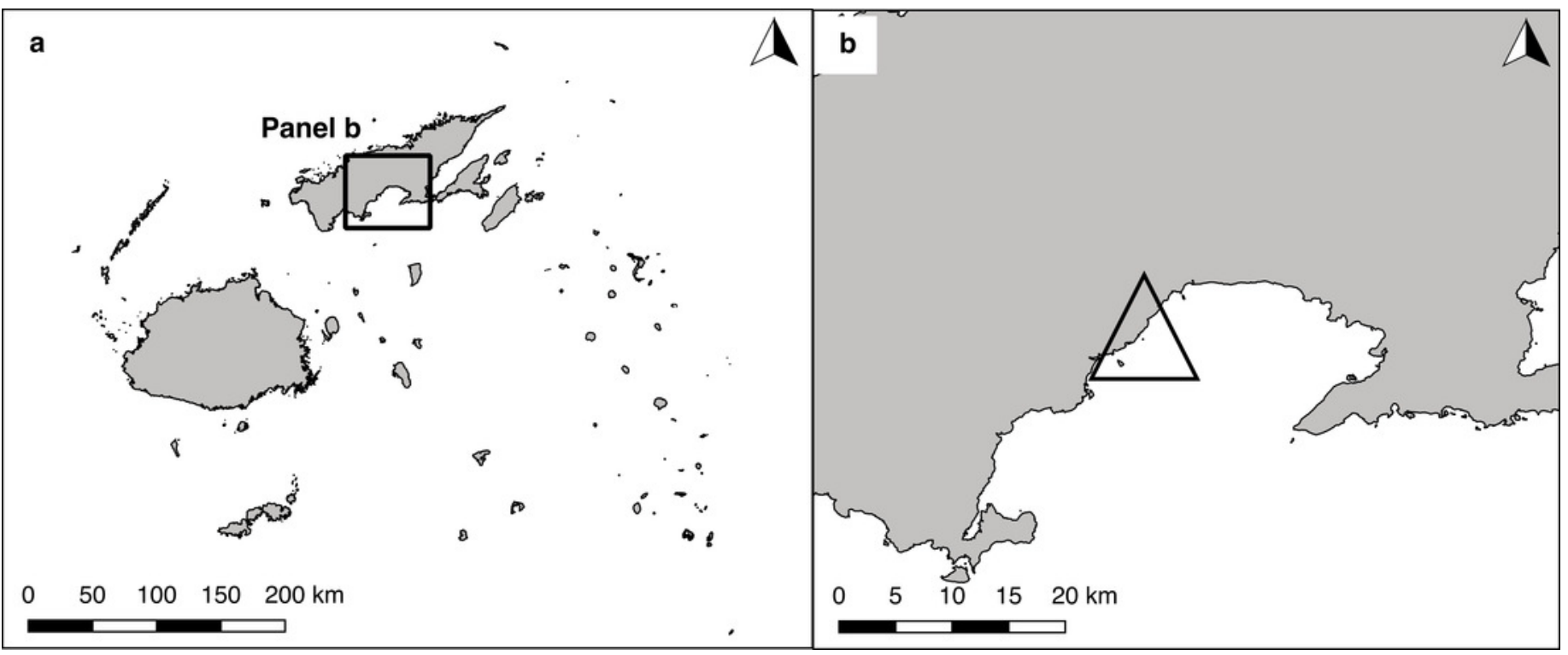




\section{Figure 2 (on next page)}

Plots of results for temperature and rainfall (a), oxygen penetration depth (b), and sediment oxygen consumption (c), at each sampling time 

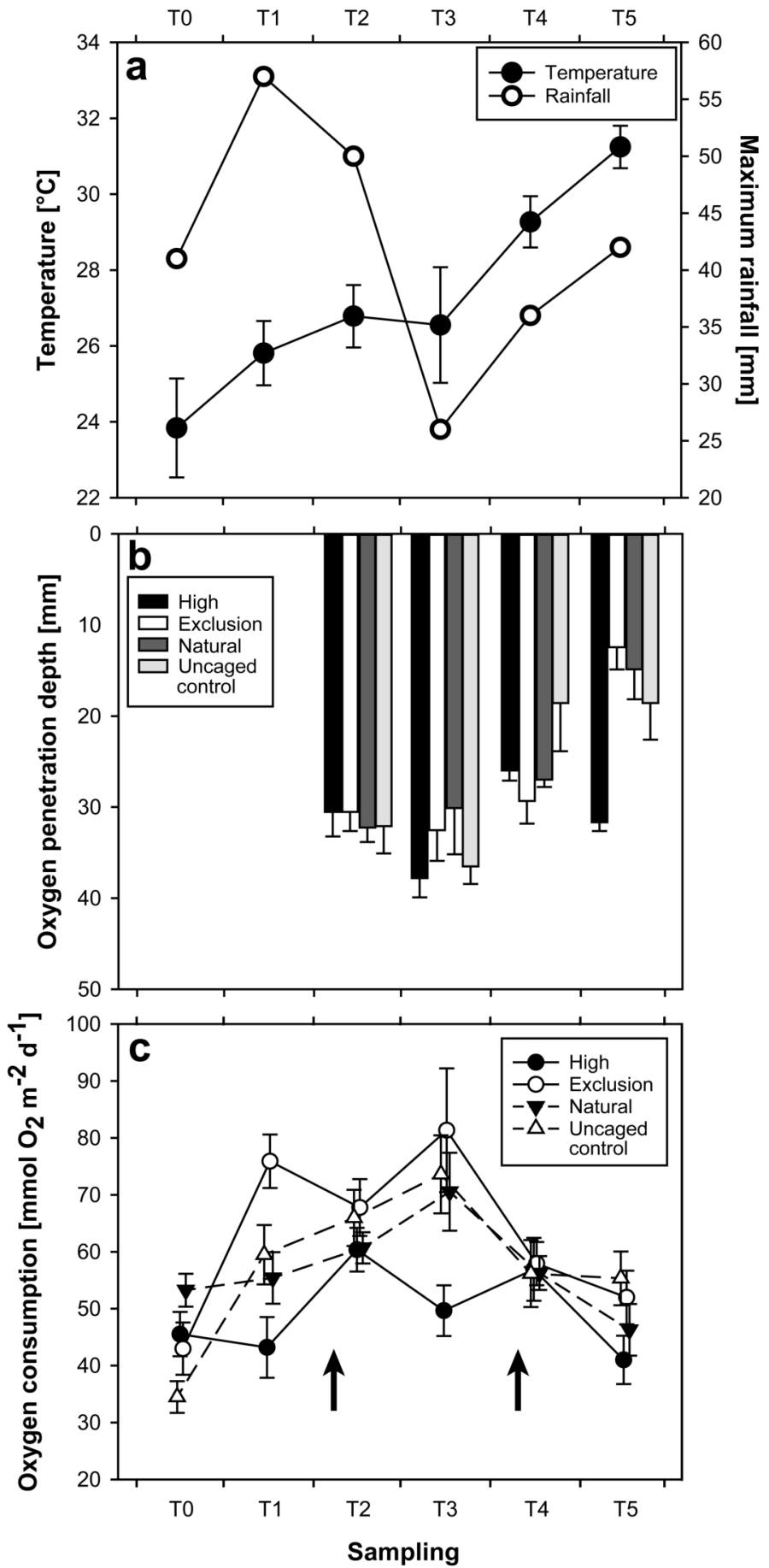


\section{Table $\mathbf{1}$ (on next page)}

Amount of sediment bioturbated by a population of Holothuria scabra.

Average $H$. scabra densities are taken from Lee et al., (unpublished data), quantity of sediment defecated is assumed equal to that consumed, and sea cucumbers are assumed to consume only the upper $5 \mathrm{~mm}$ of sediment (Uthicke, 1999). 
1

Bioturbation potential of $\boldsymbol{H}$. scabra ${ }^{-1}$

\begin{tabular}{|c|c|c|}
\hline defecation rate & 26 sediment pellets $\mathrm{h}^{-1} \times 10 \mathrm{~h} \mathrm{~d}^{-1}$ & 260 pellets $\mathrm{d}^{-1}$ \\
\hline defecation quantity & 260 pellets $\mathrm{d}^{-1} \times 0.36 \mathrm{~g}$ pellet ${ }^{-1}$ & $93.6 \mathrm{~g} \mathrm{~d}^{-1}$ \\
\hline annual defecation rate & $93.6 \mathrm{~g} \mathrm{~d}^{-1} \times 365 \mathrm{~d}$ & $34.164 \mathrm{~kg}$ ind $\mathrm{y}^{-1}$ \\
\hline \multicolumn{3}{|c|}{ H. scabra population bioturbation $\left(1000 \mathrm{~m}^{-2}\right)$} \\
\hline ca. 310 H. scabra & 310 ind. $\times 34.164 \mathrm{~kg}$ ind. $\mathrm{y}^{-1}$ & $10,590.84 \mathrm{~kg} \mathrm{y}^{-1}$ \\
\hline \multicolumn{3}{|c|}{ Available sediment (upper 5 mm) } \\
\hline area & & $1000 \mathrm{~m}^{2}$ \\
\hline volume of sediment & $1000 \mathrm{~m}^{2} \times 0.005 \mathrm{~m}$ & $5 \mathrm{~m}^{2}$ \\
\hline weight of sediment & $5 \mathrm{~m}^{2} \times 0.83 \mathrm{~g} \mathrm{~cm}^{-3}$ & $4,150 \mathrm{~kg}$ \\
\hline
\end{tabular}

Sediment turnover rate (upper $5 \mathrm{~mm} 1000 \mathrm{~m}^{-2}$ )

$10,590.84 \mathrm{~kg} \mathrm{y}^{-1} / 4,150 \mathrm{~kg} \quad 2.55$ times $\mathrm{y}^{-1}$

